\title{
Emerging technologies and their application in higher education
}

\section{Tecnologías emergentes y su aplicación en la educación superior}

\author{
RODRÍGUEZ-PÉREZ, Ivonne*† \\ Universidad Autónoma del Estado de México \\ ID $1^{\text {st }}$ Author: Ivonne, Rodríguez-Pérez / ORC ID: 0000-0003-2982-2676, Researcher ID Thomson: B-2499-2016, CVU \\ CONACYT ID: 57736
}

DOI: 10.35429/JEDT.2019.4.3.15.21

Received March 20, 2019 Accepted June 30, 2019

\begin{abstract}
The usefulness of Information and Communication Technologies (ICT) as pedagogical tools have been widely studied, where the need for didactic planning arises so that they become resources for improving educational quality. Emerging technologies are new creations, scientific innovations that can create a new industry or transform an existing one with new technologies, or also allow the use of existing ones mixed with new ones, or improve them based on new requirements. These technologies have some tools such as those listed below: Cloud Computing, Collective Intelligence, Nashua Data, Collaborative Web. The aim is to identify the knowledge that the teachers of the UAEM Valle de México University Center have, regarding emerging ICT, describe the uses that they give to some of these tools and determine their level of updating. We used a mixed methodology, to know, how are they integrated in teaching? What cognitive skills have been promoted with them?
\end{abstract}

Emerging technologies, Higher education,
Strategies, Learning

\section{Resumen}

La utilidad de las Tecnologías de la Información y la Comunicación (TIC) como herramientas pedagógicas han sido ampliamente estudiadas, en donde surge la necesidad de una planificación didáctica para que se conviertan en recursos de mejora para la calidad educativa. Las tecnologías emergentes son nuevas creaciones, innovaciones científicas que pueden crear una nueva industria o transformar una existente con tecnologías nuevas, o también permite el uso de las existentes mezcladas con las nuevas, o bien, mejorarlas a partir de nuevos requerimientos. Dichas tecnologías cuentan con algunas herramientas como las que se enlistan a continuación: Cómputo en la nube, Inteligencia colectiva, Nashua de datos, Web colaborativa. Se pretende identificar el conocimiento que tienen los docentes del Centro Universitario UAEM Valle de México, referente las TIC emergentes, describir los usos que le dan a algunas herramientas de éstas y determinar su nivel de actualización. Se utilizó una metodología mixta, para conocer, cómo se integran en la enseñanza? qué habilidades cognitivas se han promovido con ellas?

Tecnologías emergentes, Educación superior, Estrategias, Aprendizaje

Citation: RODRÍGUEZ-PÉREZ, Ivonne. Emerging technologies and their application in higher education. Journal-Economic Development Technological Chance and Growth. 2019. 3-4: 15-21

\footnotetext{
* Correspondence to Author (email: irodriguezperez@yahoo.com)

$\dagger$ Researcher contributing first author.
} 


\section{Introduction}

Today, there is no doubt that emerging technologies are called to profoundly modify teaching. But for this to happen, there will have to be an authentic review of the pedagogical use that is currently being given.

Modern organizations demand people with skills for problem solving, decision making, collaborative work capacity and flexible adaptation to rapid changes that occur in the knowledge society. Technology-supported education offers opportunities to renew content and teaching methods that allow developing those skills.

The new training scenarios are influenced by three relevant factors: the presence of the Internet, with Web 2.0 and 3.0, networks and the cloud promote and develop new ways of thinking, producing, communicating, researching, knowing, working, learning and teach; in parallel there is a growing availability of free-use technological resources (simulations, remote laboratories, videos, blogs, podcasts, forums, etc.) and along with it, a growing access to technologies by potential students (Internet, iPod, netbook, tablet, smart phone, among others).

Education requires fulfilling its functions with quality, generating spaces that lead to an appropriate pedagogical relationship between the teacher and student, establishing a type of link that channels the best of their strategies, capacities and intentions. The National Association of Universities and Institutions of Higher Education (ANUIES) made public a proposal of Higher Education for the 21st Century, where some of the challenges that universities have to face to develop the professional profiles demanded by today's society are exposed. Among these are:

Turn the University into a gateway to the knowledge society.

Attend with quality a student population in constant growth, as a result of the demographic dynamics of the country and the expansion of higher education enrolment.
Offer high quality educational services that provide students with humanistic and cultural training, with a solid technical and scientific training.

ICTs constitute a social phenomenon of great importance, especially in education, where different tools are increasingly used to support research, teaching and learning.

In this case, emerging technologies are being incorporated into education. But how do they integrate into teaching? The development of what cognitive skills have been promoted with them?

The general objective of this work is to identify the knowledge that teachers of the UAEM Valle de México University Centre have, referring to emerging ICTs, in addition to describing their uses and determining their level of updating, since these technologies have been incorporated as teaching resources and resources. The methodology used is mixed, since qualitative and quantitative data were handled.

The article has the following sections, Emerging technologies, cloud computing, data mashup, collaborative web, collaborative intelligence, emerging technologies and education, research methodology used, results and conclusions reached.

\section{Emerging technologies}

Emerging technologies are new creations, that is, scientific innovations that can create a new industry or transform an existing one with new technologies, or that also allow the use of existing ones mixed with new ones, or, improve them from new requirements.

What are emerging technologies? There are many definitions in this regard, but here two will be considered. First that of Gregory Day and Paul Schoemaker (2011) in the book Management of emerging technologies, they define them as "scientific innovations that can create a new industry or transform an existing one. They include discontinuous technologies derived from radical innovations, as well as more evolved technologies formed as a result of the convergence of previously separated branches of research". 
The second is from Pomeda Rodríguez. J. (2008), defines emerging technologies as "modern techniques to more efficiently manage the operations-logistics binomial and have had an evolution over time directly to the advancement of information technologies".

The previous definitions indicate that the development of man includes tools and innovations that will allow the human being to live in an easier way every time he has to undertake a task. This situation will become repetitive, that is, technology changes and the human being adapts to it, evolves again from it, and man must learn to unlearn and so on, always providing a simpler and safer life.

These technologies have some tools such as those listed below: cloud computing, collective intelligence, data nashua, collaborative web.

Each of them will be explained below:

\section{Cloud computing}

Cloud computing is itself a platform that eliminates hardware and software limitations by using easy-to-use Internet resources. (Uden,2016)

This means that it is no longer necessary to worry about having a computer or mobile device with a large processing or storage capacity. It is enough to have a good amount of memory when you want to modify a document and an intermediate processing capacity.

The above is thanks to the fact that files of all kinds can be uploaded in the cloud, as providers support various formats.

When uploading files, documents are in a safe place away from malware infections or attacks of this type.

Some examples: Google applications (office automation), Dropbox, Apple ICloud, Mega, Copy, Box and MediaFire, Amazon, WebServices, Google Cloud Platform, Windows Azure, Dataprius, among others.

\section{Collective intelligence}

Collective intelligence is seen as a set of ideas, action or product for a common purpose. (Vilchis,2019)

Collective intelligence allows you to evaluate tools and take the best ones for a particular case, it is also a support to create projects or works together within a multidisciplinary working group or the same discipline. Those involved are enriched by the proposals of their peers to obtain a better result.

Examples: Google, Wikipedia, YouTube, Pinterest, Canva, etc.

\section{Data mashup}

Data Mashup is considered a hybrid Web application. (Arroyo,2014)

In other words, it is a personalized Web environment that reuses existing network technology features from many sources in order to take the best features of each technology and join them to solve a problem or reach a solution in less time and with better quality.

A data mashup is a mix of customized technologies according to the needs of the work team or perhaps of a single person.

It can have a technology or more than two. The number of technologies involved depends on the needs of the work team and what you want to solve or investigate. Some examples: quSquidoo, Panoramic, Tagzania, Ugato, Googlemark, Pixagogo Maps, etc.

In this case we find Tagzaia, which allows us to add routes, areas and polygons of places that are visited, Squidoo is a communal publishing platform that allows you to consult flyers, bookmarks or overview articles.

\section{Collaborative Web}

The collaborative website consists of groups of people who develop a theme to generate collective knowledge and solve the greatest number of problems. (Vilchis, 2019) This can be confused with collective intelligence, but in reality, both tools can be used together. 
With the collaborative web you can give life to the brainstorm generated by means of tools found on the Web. In fact, the four tools allow team work and together they can generate knowledge and help exploit the advantages of the Web.

Some examples: Facebook, MySpace, Skype, Wikipedia, Google Documents

In summary, these emerging technologies serve as support between them for various activities and can be tailored to various needs.

\section{Emerging Technologies and Education}

Emerging technologies have been proposing since its inception, a paradigm shift in education, where teachers must develop new skills and abilities in a digital environment, and education institutions must be periodically revaluing their curricula and teaching schemes and methods of evaluation, with all that this implies in operational, technical and technological terms, in such a way that they guarantee an ideal preparation of the teachers to their students.(Day, 2011)

Emerging technologies have allowed educational institutions to take advantage of the various tools available on the web, incorporating them into their activities, tending to improve the apprehension of knowledge in the student, in which certain indicators are generated, which are the metric to establish the viability of these tools in and out of classrooms, which will subsequently be used in the reformulation of future curricula and educational policies.

In order to manage and / or administer web tools of emerging technologies, it is essential that the teacher researches and is constantly updated in this regard, in order to acquire sufficient knowledge and skills to understand and manage the new applications and technologies of the ICT, where the learning environment has been migrating from analogue classrooms, to digital classrooms, in which there is an ideal medium for student and even teacher learning.

\section{Methodology to develop}

Considering all of the above, the Autonomous University of the State of Mexico is constantly transforming academic programs in accordance with the guidelines of the flexible model based on constructivism and incorporating the use of technology in the teaching-learning process and developing digital skills, where teachers have a constant commitment to be updated as they will collaborate in the formation of new generations. From this situation, the Valle de México University Centre is interested in identifying the emerging technologies that the teacher uses in the classroom, as support to facilitate student learning.

The research approach is mixed cut. This process collects; analyse and link quantitative and qualitative data in the same study, or a series of investigations to respond to the problem statement. Also, the mixed approach can use both approaches to answer different research questions (Galeano, 2007). The instrument that was used to collect the information was a questionnaire, which was divided into two sections, in addition to making an interview with teachers. The total population of teachers of the University Centre is 210, but only 100 (10 of each educational program) were considered since it is a bit difficult to find them to give them the questionnaire to respond personally.

The questionnaire was provided when they attended to teach their classes, they were not sent by mail since they wanted to ensure that they will answer them. The professors belong to the different ones by careers that are taught in the space, being in total 10 educational programs, Accounting, Administration, Administrative Informatics, Actuary, International Economic Relations, Economics, Computer Engineering, Systems and Communications Engineering, Industrial Engineering and right.

The procedure that was carried out for the collection of the information was to apply a questionnaire to the teachers, which was divided into two sections, the first would allow to know the teacher's profile, the next to know the degree of knowledge and management of the emerging technologies that they used in class and an interview, in which qualitative information was obtained regarding the use of emerging technologies. 


\section{Results}

Next, the analysis of the data obtained from the application of the questionnaire will be given. As the sample has teachers from each of the educational programs, there are: accountants, administrators, lawyers, economists, actuaries, engineers and computer scientists.

Regarding gender and age, the percentage of men is slightly higher than that of women, the percentage of women is $43 \%$ and that of men is $57 \%$, as shown in table 1 . The ages are in the range 30-63 years old. The data obtained are shown in table 2 .

\begin{tabular}{|l|l|l|}
\cline { 2 - 3 } \multicolumn{1}{c|}{} & \multicolumn{1}{l}{ Frequency } & \multicolumn{1}{l|}{ Percentage } \\
\hline Male & 57 & $57 \%$ \\
\hline Female & 43 & $43 \%$ \\
\hline Total & 100 & $100 \%$ \\
\hline
\end{tabular}

Table 1 Genre

Source: Own Elaboration

\begin{tabular}{|l|l|l|}
\cline { 2 - 3 } \multicolumn{1}{c|}{} & Frequency & Percentage \\
\hline $30-40$ & 15 & $15 \%$ \\
\hline $40-50$ & 37 & $37 \%$ \\
\hline $50-60$ & 28 & $28 \%$ \\
\hline More than 50 & 20 & $20 \%$ \\
\hline Total & 100 & $100 \%$ \\
\hline
\end{tabular}

Table 2 Age

Source: Own Elaboration

When asked if they knew about emerging technologies, $78 \%$ of the teachers answered no and $22 \%$ did. The results are shown in graphic 1.

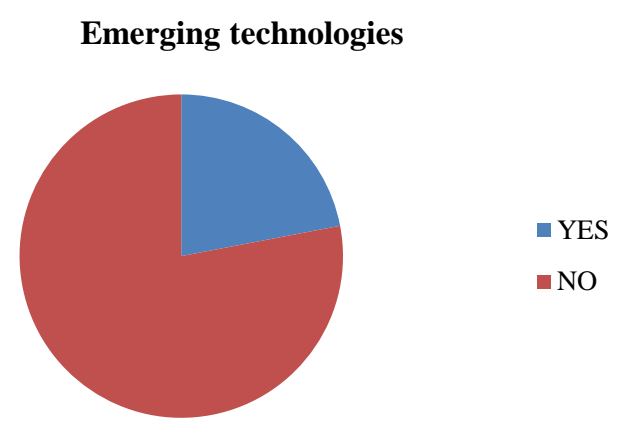

Graphic 1

Source: Own Elaboration

When they were explained what the emerging technologies were, the teachers said that they knew them, but not with that name. So, he provided them with a list of some tools belonging to this category and they were asked which ones they used, the results are shown in Figure 2:

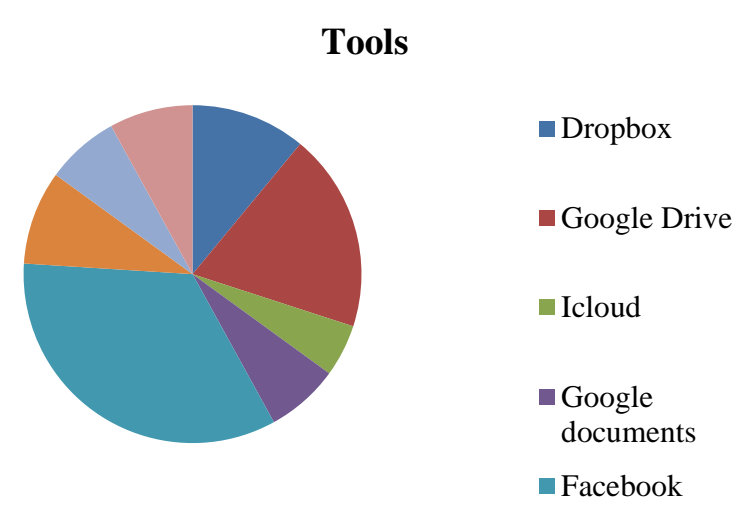

Graphic 2

Source Own Elaboration

It is observed that the most used tool is Facebook with $34 \%$ for personal use only, not as a didactic tool. Google drive and Dropbox use it to store personal documents and, in some cases, to share information about their classes with students. YouTube uses it as a didactic tool, since they look for videos referring to their subjects they teach and for students to make videos. The other tools presented to them are for personal use only.

The devices where they use these tools are your cell phone or your personal computer. As you can see, teachers do not use emerging technologies as a teaching tool and are not very up-to-date in their use.

\section{Conclusions}

Technologies are considered to be advancing at high speed, while didactics, pedagogy and ways of teaching do not do so at the same pace. Today, backward systems are used to understand learning and to understand the new ways of learning of students, which do not allow an improvement in the learning experience and do not understand that the tools to educate are transformed day by day. Teachers teach as they were taught and lack a better level of training so that they can be on par with their students, that is, lack of pedagogical versatility.

There must be a radical change in tools, pedagogies, didactics and student-oriented practices. It should be noted that ICTs are born with very different purposes than educational ones, in general, they are directed to industry, commerce and then they return to education, and when they begin to be used in this field, technologies change again, causing education is one step back from technological advances. 
A very thorough study on the integration of ICT in teaching-learning processes must be done and new ways to implement the pedagogy that technology uses in new educational strategies, with the change of mentality, attitude and culture by teachers, because although emerging technologies by themselves do not improve teaching-learning they do facilitate the process and make students more creative and as a result collectively build new knowledge.

Much of the information and knowledge has been digitized, and anyone can create, transform and share information with another or group of people. This has had an impact on education, and that is that technologies have become an educational tool. Emerging technologies are instruments to improve learning, student engagement, and the education system in general.

Using emerging technology to address educational objectives makes it necessary to develop theories, pedagogies and learning approaches in accordance with these.

Digital technologies are tools at the service of pedagogy, and that are integrated in education through teaching practice, not in the use of ICT. The integration of technology from this approach, open, participatory and autonomous teaching-learning processes can be achieved.

It is essential that, from university classrooms, new media can be integrated with new ways of making educational work not obsolete but innovative, that responds to the current context, to train future professionals to function competently in a technological world of work, where knowledge is shared, from a participatory culture that promotes collective intelligence and the generation of learning communities.

\section{References}

Adell J. y Castañeda L. (2012). Tecnologías emergentes, ¿pedagogías emergentes? En L.Hernández, M. Pennesi, D. Sobrino y A. Vázquez (coord.). Tendencias emergentes en educación con TIC. Barcelona: Asociación Espiral, Educación y Tecnología, pp. 13-32
Aghaei S., Nematbakhsh M. y H. Farsani. (2012). Evolution of the world wide web: from web 1.0 to web 4.0, International Journal of Web \& Semantic Technology (IJWesT), vol.3, No.1, pp. 1-10, doi: 10.5121/ijwest.2012.3101

Aquino A. (2019). Evolución de la web. Ingeniería Informática-TAI 2, Universidad Católica "Nuestra Señora de la Asunción".. Disponible en: http://jeuazarru.com/wpcontent/uploads/2019/06/Evolucion-de-la web.pdf

Arroyo V. Natalia (2014). ¿Web 2.0? ¿web social? ¿qué es eso?. e-Lis e-prints in library \& information science http://eprints.rclis.org/10566/. Consultado el 29 de marzo de 2019

Bautista J., Espigares M. y Duarte M.. (2016). Internet y tecnologías emergentes en educación en el marco de un nuevo horizonte cognitivo. Revista Científica de la UCSA, vol.3, No. 1, pp. 67-77.

Day G., Schoemaker, P. (2011). Gerencia de tecnologías emergentes. Recuperado el 10 de junio de 2019 del sitio Web: http://tecmethepelonex.blogspot.com/2008/8/ini cion-tecnologias-emergentes.html

Fernández A., G. Server y R. Carballo (2006). Aprendizaje con nuevas tecnologías paradigma emergente. ¿Nuevas modalidades de aprendizaje? Rev. Electrónica de Tecnología Educativa, No. 20, pp. 1-24.

Fernández R., Server P. y Carballo E.. (s.f.) Aprendizaje con nuevas tecnologías paradigma emergente. ¿Nuevas modalidades de aprendizaje?. Disponible en: https://educrea.cl/ aprendizaje-con-nuevas-tecnologias-paradigmaemergente-nuevas-modalidades-de-aprendizaje/

Hermosa P. (2015). Influencia de las tecnologías de información y comunicación (TIC) en el proceso enseñanza-aprendizaje: una mejora de las competencias digitales. Rev. Cient. Gen. José María Córdova, vol. 13, No. 16, pp. 121-132.

Padilla J., Vega P. y Rincón D.. (2013). Tendencias y dificultades para el uso de las TIC en educación superior, Entramado, vol. 10 No.1, pp. 272-295. 
Pomeda, R. J. (2008). Indicadores del Sistema Español de Ciencia y Tecnología. Disponible en: www.madrimasd.org/

revista/revista9/biliografia/bibliografias2.asp

Uden L., Liberona D. y Feldmann B. (2016). Learning Technology for Education in Cloud: The Changing Face of Education. Germany, Springer Verlag. doi 10.1007/978-3-319-421476

Utrera, G.F., (2012). Estrategias Web 2.0 para la enseñanza. Cancún, Q. Roo, México. Primera edición.

Vilchis R, Mario Arturo. (2019).La Web 2.0 y la nube. Universidad Autónoma del Estado de Hidalgo. Sistema de Universidad Virtual. Consultado el 28/06/19. 